\title{
Tourist Satisfaction Based Marketing Research for Domestic Tourist Market of Jiangsu Province
}

\author{
Li-Jiao JIN ${ }^{1, a}$, Wei TU ${ }^{1, b}$ \\ ${ }^{1}$ Nanjing Institute of Tourism \& Hospitality, Nanjing 211100, Jiangsu Province, China \\ a3075231256@qq.com, b563109691@qq.com
}

Key words: Tourist satisfaction; Jiangsu; marketing for domestic tourist market; marketing strategy

\begin{abstract}
This paper, with the domestic tourist market of Jiangsu Province as research object, revealed through tourist satisfaction indicator system the fact that the domestic tourist satisfaction at Jiangsu Province has not yet reached the level of satisfaction, and that difference existed in satisfaction between different tourist groups; additionally, this paper identified 13 significant factors affecting tourist satisfaction. On this basis, this paper proposed the marketing strategy for Jiangsu's domestic tourist market.

Tourist satisfaction, as derived from customer satisfaction, refers to tourists' comprehensive evaluation of the extent to which the tourism landscapes, infrastructures, tourism environment and social service etc. satisfy their requirements for tourism activities ${ }^{1}$. Along with the increasingly fierce competition in sightseeing places, market orientation has become an inevitable choice of tourism development; tourist satisfaction analysis is exactly an important way to learn about tourists and market.
\end{abstract}

\section{General situation of domestic tourist market in Jiangsu Province}

Tourists on the domestic tourist market of Jiangsu Province mainly come from Jiangsu Province itself, while the proportion of tourists from other provinces may fluctuate from time to time. The average proportion of tourists from Jiangsu during the period from 2001 to 2012 is $41.21 \%$, while the proportion of tourists from other provinces was constantly $58.79 \%^{2}$. The top five external sources of tourists over the more than one decade were Shanghai, Zhejiang, Anhui, Shandong, and Guangdong. With respect to seasonal characteristics, the domestic tourism market received "fewer tourists in winter, and more in summer". As for the selection of tourism products, most tourists $(43.20 \%)$ selected sightseeing; the tourists of leisure vacation (16.63\%) and business activities (13.84\%) accounted for a large proportion; the proportions of other types of tourists did not exceed $10 \%$. With regard to the consumption structure of domestic tourists, the sum of revenue from long-distance transportation, accommodation, catering and scenic spots accounted for more than $70 \%$ of total domestic tourism revenue. This shows that tourists' expenditures for basic consumption items still account for the main part of consumption, while not enough consumption has corresponded to high-grade and highly value-added products like entertainment, which indicates that further efforts shall be made to extend the depth of tourism products ${ }^{3}$.

\section{Research Methods and Data Sources}

\section{Research Design and Method}

Whether or not expectation may affect tourist satisfaction has been a controversial topic in the academic circles. In this context, the tourist satisfaction evaluation system proposed by some scholars holds that the overall satisfaction of tourists is associated with the six factors, service and facilities of tourism ${ }^{4}$. Along with the development of the times, the improvement of tourists' artistic appreciation, and the popularity of smart tourism, the satisfaction of tourists also involves the surroundings, tourism atmosphere and internet access etc. On this ground, this paper, through the synthesis of various affecting factors, established the domestic tourists satisfaction evaluation 
indicator system (Table 1) of Jiangsu Province involving 9 dimensions and 24 factors. By Likert 5-level scale method, this paper set up an evaluation set $\mathrm{V}=$ \{very satisfied; satisfied; moderately satisfied; somewhat dissatisfied; and very dissatisfied \}, and defined the corresponding measurement scale vectors $\mathrm{H}=\{5,4,3,2,1\}$ used as corresponding scores of evaluation set.

Table 1 Domestic tourists satisfaction evaluation indicator system of Jiangsu Province

\begin{tabular}{|c|c|c|}
\hline $\begin{array}{l}\text { General } \\
\text { objective }\end{array}$ & $\begin{array}{l}\text { Evaluation } \\
\text { dimension }\end{array}$ & Evaluation factor \\
\hline \multirow{9}{*}{ 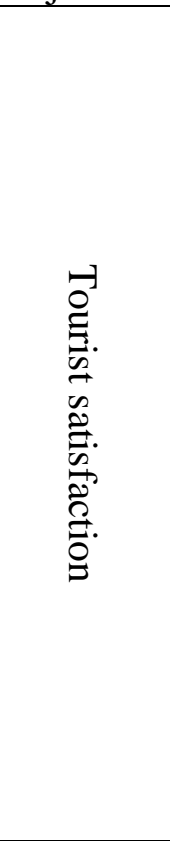 } & $\begin{array}{c}\text { Tourism } \\
\text { environment }\end{array}$ & Public security, and sanitary condition \\
\hline & Tourism atmosphere & Natural scenery, and cultural heritage \\
\hline & Tourism catering & $\begin{array}{l}\text { Attitude towards customers, service quality, dining } \\
\text { environment and facilities, and catering price }\end{array}$ \\
\hline & $\begin{array}{c}\text { Tourist } \\
\text { accommodation }\end{array}$ & $\begin{array}{c}\text { Attitude towards customers, accommodation setting } \\
\text { \& facilities, and accommodation price }\end{array}$ \\
\hline & $\begin{array}{c}\text { Tourist } \\
\text { communications }\end{array}$ & $\begin{array}{l}\text { Transportation convenience, comfort, and transport } \\
\text { price }\end{array}$ \\
\hline & Tourist attraction & $\begin{array}{l}\text { Quantity and grade of scenic resources, scenic } \\
\text { environment and facilities, scenic spot ticket }\end{array}$ \\
\hline & Tourist shopping & $\begin{array}{l}\text { Quality and characteristics of tourist commodities, } \\
\text { shopping environment, tourist commodities price }\end{array}$ \\
\hline & Tourist recreation & $\begin{array}{c}\text { Participatory extent of recreational activities, } \\
\text { entertainment facilities, and the price of recreational } \\
\text { activities }\end{array}$ \\
\hline & Internet access & Network signal intensity, network coverage \\
\hline
\end{tabular}

This paper determined tourists' overall satisfaction in Jiangsu and their satisfaction with evaluation factors included in the indicator system by means of questionnaire survey ${ }^{5}$, identified the important factors affecting tourist satisfaction through Pearson correlation coefficient check, and discussed the difference in satisfaction of various tourist groups through one-factor analysis of variance etc., thereby presenting the suggestions on improvement of domestic tourism marketing strategy for Jiangsu.

\section{Data Source}

The survey data was obtained through field survey at eight important scenic spots of Jiangsu Province performed by teachers from Nanjing Institute of Tourism \& Hospitality from June to August, 2012 with the assistance of Jiangsu Provincial Tourist Administration; a total of 800 questionnaire sheets were distributed; 756 were returned; 635 were valid questionnaire sheets, and the effective rate was $84 \%$.

The conclusion was reached after statistical analysis of sample data of questionnaire survey with statistical analysis software SPSS 19.0. In this survey, Alpha $=0.910$, while the Alpha reliability coefficient of each evaluation factor was greater than 0.909 , which indicated high reliability (credibility) of questionnaire survey data.

\section{Survey Result and Analysis}

\section{Satisfaction Evaluation}

Statistical analysis showed the overall tourist satisfaction value was 3.93. This means the overall satisfaction of domestic tourists in Jiangsu Province has not yet reached the level of satisfaction. Accordingly, the domestic tourism market marketing strategy of Jiangsu Province exhibited certain room for improvement. 
It is observed from the satisfaction value of each evaluation factor (Table 2) that the public security, natural scenery and the quantity and grade of scenic resources reached the satisfied level, while others were slightly above average. The lowest satisfaction value corresponded to tourism commodity price followed by scenic spot ticket, catering price, and the quality and characteristics of tourism commodities. This means domestic tourists in Jiangsu Province had a general feeling during the process of tourism that local scenic spot ticket price, commodity price and catering price were excessively high, while tourism commodities were not distinctive and high-quality.

Table 2 Satisfaction value of evaluation factor

\begin{tabular}{|l|c|l|c|}
\hline \multicolumn{1}{|c|}{ Evaluation factor } & $\begin{array}{c}\text { Satisfaction } \\
\text { value }\end{array}$ & \multicolumn{1}{|c|}{ Evaluation factor } & $\begin{array}{c}\text { Satisfaction } \\
\text { value }\end{array}$ \\
\hline Public security & 4.00 & Communication price & 3.79 \\
\hline Sanitary condition & 3.86 & $\begin{array}{l}\text { Quantity and grade of } \\
\text { scenic resources }\end{array}$ & 4.08 \\
\hline Natural scenery & 3.87 & $\begin{array}{l}\text { Scenic environment and } \\
\text { facilities }\end{array}$ & 3.96 \\
\hline Cultural deposits & 3.73 & $\begin{array}{l}\text { Qcenic spot ticket } \\
\text { characteristics of tourist } \\
\text { commodities }\end{array}$ & 3.64 \\
\hline $\begin{array}{l}\text { Catering service attitude and } \\
\text { quality }\end{array}$ & 3.74 & Shopping environment & 3.68 \\
\hline Dining environment and facilities & 3.64 & $\begin{array}{l}\text { Price of tourist } \\
\text { commodities }\end{array}$ & 3.60 \\
\hline Catering price & 3.76 & $\begin{array}{l}\text { Participatory extent of } \\
\text { recreational activities }\end{array}$ & 3.70 \\
\hline $\begin{array}{l}\text { Accommodation service attitude } \\
\text { and quality }\end{array}$ & 3.78 & Entertainment facilities & 3.75 \\
\hline $\begin{array}{l}\text { Accommodation environment } \\
\text { and facilities }\end{array}$ & 3.70 & $\begin{array}{l}\text { Price of recreational } \\
\text { activities }\end{array}$ & 3.68 \\
\hline Accommodation price & 3.92 & Network signal intensity & 3.67 \\
\hline Transportation convenience & 3.79 & Network coverage & 3.71 \\
\hline $\begin{array}{l}\text { Degree of comfort of } \\
\text { communication }\end{array}$ & & & \\
\hline
\end{tabular}

\section{Satisfaction Difference Analysis}

Based on the information about overall satisfaction and individual satisfaction of domestic tourists, this paper further probed into the difference in satisfaction between tourist groups with different demographic characteristics and tourist behavior characteristics through single-factor variance analysis and independent sample T test. (See Table 3)

$\mathrm{P}$ value indicates the extent of difference in satisfaction between various groups of tourists: $\mathrm{P}>$ 0.05 means the difference is not significant; $0.01<\mathrm{P}<0.05$ means significant difference; $\mathrm{P}<0.01$ means the difference is extremely significant. As shown in Table 3, the tourist satisfaction exhibits significant differences in respect of tourist source, age, and travel planning etc. Details are described as follows: Satisfaction of tourists from Jiangsu Province is higher than that of tourists from other provinces; as for age difference, tourist satisfaction exhibits a U-shaped structure, where the 25-44 years old tourists showed the lowest satisfaction; the more detailed the travel plan is, the higher the satisfaction would be. Insignificant difference was found in satisfaction of other different tourist groups. 
Table 3 Analysis of satisfaction difference between different tourist groups

\begin{tabular}{|c|c|c|c|c|c|c|c|}
\hline Items & Variable & $\begin{array}{c}\text { Satisfactio } \\
\text { n value }\end{array}$ & $\begin{array}{l}\mathrm{F} \text { value/ } \\
\mathrm{P} \text { value }\end{array}$ & Items & Variable & $\begin{array}{c}\text { Satisfactio } \\
\mathrm{n} \text { value }\end{array}$ & $\begin{array}{l}\mathrm{F} \text { value/ } \\
\mathrm{P} \text { value }\end{array}$ \\
\hline \multirow{2}{*}{$\begin{array}{l}\text { Tourist } \\
\text { source }\end{array}$} & $\begin{array}{l}\text { Inside } \\
\text { Jiangsu } \\
\text { Province }\end{array}$ & 3.80 & $\begin{array}{l}5.209 / \\
0.001\end{array}$ & \multirow{4}{*}{$\begin{array}{c}\text { Household } \\
\text { income }\end{array}$} & $\begin{array}{l}3,000 \text { Yuan } \\
\text { or less }\end{array}$ & 3.90 & $\begin{array}{l}2.002 / \\
0.076\end{array}$ \\
\hline & $\begin{array}{l}\text { Outside } \\
\text { Jiangsu } \\
\text { Province }\end{array}$ & 3.72 & & & $\begin{array}{l}3,001-5,000 \\
\text { Yuan }\end{array}$ & 3.88 & \\
\hline \multirow[t]{2}{*}{ Gender } & Male & 3.92 & $\begin{array}{l}0.548 / \\
0.459\end{array}$ & & $\begin{array}{l}5,000-10,00 \\
0 \text { Yuan or } \\
\text { more }\end{array}$ & 4.03 & \\
\hline & Female & 3.94 & & & $\begin{array}{l}\text { More than } \\
10,000\end{array}$ & 3.93 & \\
\hline \multirow{5}{*}{ Age } & Under 14 & 4.08 & $\begin{array}{l}2.510 / \\
0.040\end{array}$ & \multirow{3}{*}{\begin{tabular}{|c|} 
Number of \\
travels to \\
Jiangsu
\end{tabular}} & 1 & 3.89 & $\begin{array}{l}2.488 / \\
0.059 \\
\end{array}$ \\
\hline & $14-24$ & 3.93 & & & 2 & 3.88 & \\
\hline & $25-44$ & 3.88 & & & Several & 4.00 & \\
\hline & $45-64$ & 4.02 & & \multirow{3}{*}{ Travel plan } & $\begin{array}{l}\text { Not } \\
\text { prepared }\end{array}$ & 3.80 & $\begin{array}{l}5.322 / \\
0.005 \\
\end{array}$ \\
\hline & Above 65 & 4.16 & & & $\begin{array}{l}\text { Slightly } \\
\text { prepared }\end{array}$ & 3.82 & \\
\hline \multirow{10}{*}{ Occupation } & $\begin{array}{l}\text { Public } \\
\text { servants }\end{array}$ & 3.95 & $\begin{array}{l}1.261 / \\
0.230\end{array}$ & & $\begin{array}{l}\text { Prepared in } \\
\text { detail }\end{array}$ & 3.97 & \\
\hline & $\begin{array}{l}\text { Enterprise } \\
\text { and } \\
\text { institution } \\
\text { managemen } \\
\text { t personnel } \\
\end{array}$ & 3.89 & & \multirow{4}{*}{$\begin{array}{l}\text { Travel } \\
\text { mode }\end{array}$} & Tour group & 4.11 & $\begin{array}{l}1.083 / \\
0.372\end{array}$ \\
\hline & $\begin{array}{l}\text { Professional } \\
\text { s/culture \& } \\
\text { education } \\
\text { technicians }\end{array}$ & 3.85 & & & Family DIY & 3.85 & \\
\hline & $\begin{array}{l}\text { Service/sale } \\
\text { s/trading } \\
\text { personnel }\end{array}$ & 3.85 & & & Tour pal & 3.63 & \\
\hline & Workers & 3.86 & & & $\begin{array}{l}\text { Travel } \\
\text { alone }\end{array}$ & 4.14 & \\
\hline & Peasants & 3.94 & & & & & \\
\hline & $\begin{array}{l}\text { Military } \\
\text { personnel }\end{array}$ & 4.00 & & \multirow{3}{*}{$\begin{array}{l}\text { Degree } \\
\text { of } \\
\text { educatio } \\
n\end{array}$} & $\begin{array}{l}\text { College } \\
\text { degree or } \\
\text { lower }\end{array}$ & 3.96 & $\begin{array}{l}1.435 / \\
0.238\end{array}$ \\
\hline & Students & 3.93 & & & $\begin{array}{l}\text { Bachelor's } \\
\text { degree }\end{array}$ & 3.89 & \\
\hline & Retirees & 3.88 & & & $\begin{array}{l}\text { Master's } \\
\text { degree or } \\
\text { higher }\end{array}$ & 3.92 & \\
\hline & $\begin{array}{l}\text { Other } \\
\text { occupations }\end{array}$ & 3.99 & & & & & \\
\hline
\end{tabular}




\section{Significant Factors Affecting Satisfaction}

Pearson correlation coefficient was used to check the extent of effect of each evaluation factor on tourist satisfaction; it was observed that the correlation coefficient of 13 evaluation factors, including the quantity and grade of scenic resources, cultural deposits, natural scenery and scenic environment \& facilities (as shown in Table 4) was greater than 0.6 , while the probability value of each correlation coefficient was approaching 0 , which means these 13 evaluation factors exhibit a strong correlation with tourist satisfaction.

Table 4 Analysis of correlation of evaluation factors with tourist satisfaction

\begin{tabular}{|c|c|c|}
\hline \multicolumn{2}{|c|}{ Evaluation factor } & $\begin{array}{l}\text { Tourist } \\
\text { satisfaction }\end{array}$ \\
\hline \multirow{2}{*}{ Quantity and grade of scenic resources } & Pearson correlation coefficient & 0.832 \\
\hline & Significance (both sides) & 0.000 \\
\hline \multirow{2}{*}{ Natural scenery } & Pearson correlation coefficient & 0.830 \\
\hline & Significance (both sides) & 0.000 \\
\hline \multirow{2}{*}{ Cultural deposits } & Pearson correlation coefficient & 0.824 \\
\hline & Significance (both sides) & 0.000 \\
\hline \multirow{2}{*}{ Scenic environment and facilities } & Pearson correlation coefficient & 0.817 \\
\hline & Significance (both sides) & 0.000 \\
\hline \multirow{2}{*}{ Catering service attitude and quality } & Pearson correlation coefficient & 0.774 \\
\hline & Significance (both sides) & 0.000 \\
\hline \multirow{2}{*}{ Quality and characteristics of commodities } & Pearson correlation coefficient & 0.765 \\
\hline & Significance (both sides) & 0.000 \\
\hline \multirow{2}{*}{ Accommodation environment and facilities } & Pearson correlation coefficient & 0.733 \\
\hline & Significance (both sides) & 0.000 \\
\hline \multirow{2}{*}{ Transportation convenience } & Pearson correlation coefficient & 0.713 \\
\hline & Significance (both sides) & 0.000 \\
\hline \multirow{2}{*}{ Participatory extent of recreational activities } & Pearson correlation coefficient & 0.702 \\
\hline & Significance (both sides) & 0.000 \\
\hline \multirow{2}{*}{ Scenic spot ticket } & Pearson correlation coefficient & 0.701 \\
\hline & Significance (both sides) & 0.000 \\
\hline \multirow{2}{*}{ Catering price } & Pearson correlation coefficient & 0.700 \\
\hline & Significance (both sides) & 0.000 \\
\hline \multirow{2}{*}{ Commodity price } & Pearson correlation coefficient & 0.690 \\
\hline & Significance (both sides) & 0.000 \\
\hline \multirow{2}{*}{ Network coverage } & Pearson correlation coefficient & 0.653 \\
\hline & Significance (both sides) & 0.000 \\
\hline
\end{tabular}

\section{Marketing Strategy for Jiangsu's Domestic Tourists}

At the level of domestic tourism market, the overall tourist satisfaction with Jiangsu was not high because of such issues as excessively high price of scenic spot ticket and catering as well as the mediocrity and poor quality of tourism commodities. It's possible to effectively improve tourist satisfaction by paying attention to market segmentation, intensifying the publicity to scenic resources, mining local culture deeply, improving catering service attitude and quality, optimizing the environment, exerting reasonable control over the prices of scenic spot ticket, commodities and catering, and expanding the network coverage. 


\section{Market Strategy: Consolidate the Tourists Market at Yangtze River Delta}

By reason that the areas at Yangtze River Delta serve as each other's tourist market, the regional flow of tourists is significant. On this account, to attract tourists from the Yangtze River Delta to Jiangsu would be an important intensive and extensive development orientation of Jiangsu's tourism market. Jiangsu Province could cooperate with important tourism cities at the Yangtze River Delta, set up tourism image stores there, and turn them into the windows for long-term tourism promotion at the Yangtze River Delta for Jiangsu. This will bring about positive effect on Jiangsu's giving publicity to its tourism resources, keeping abreast of dynamic market information, developing tourism products compliant with tourists demand, and attracting more tourists from the Yangtze River Delta through nearby promotion. In addition, the new forms of tourism represented by self-d riving tour, DIY tour and free tour are rapidly replacing traditional group tour and playing a leading role in tourism market. In view of the change in the development trend of tourism, Jiangsu Province is expected to take an active part in the development of "3h tourism circle" and work with other provinces at the Yangtze River Delta to build a platform for self-driving tour and DIY tour.

\section{Product Strategy: Address Diversified Tourist Demand}

Since difference exists in tourists' preference for tourism products, Jiangsu Province shall launch tourism products on a targeted basis based on the difference in tourist demand as shown in the result of field survey. The planning for key tourism projects shall give more attention to the service function regarding leisure vacation. For example, the planning for the National Museum of Grande Canale, the Qinhuai River Tourism Zone, and the Runyang Bridge Tourist Area in Nanjing-Zhenjiang-Yangzhou-Taizhou Tourist Zone shall focus on ecological leisure development with water culture as the theme. Moreover, it should be noted that young tourists reported the lowest satisfaction. From this point of view, Jiangsu has to dig into Wu culture, strengthen participatory tourism products, and let tourists learn about the splendid culture of Jiangsu by means of "viewing, listening, speaking, singing and doing". Jiangsu's tourism commodities have higher visibility among tourists, so many tourists were attracted to Jiangsu by the well-known commodities. Unfortunately, tourists are less satisfied with the quality and features of Jiangsu's tourism commodities. The tourism commodities of Jiangsu should incorporate distinctive local characteristics and comprise local customs, being good-looking, representative and famous.

\section{Channel Strategy: Open up Network Channel of the New Era}

Along with the mushrooming of smart tourism, Jiangsu Province has to expand the coverage of network and attach importance to the important role of network in marketing. Encourage key scenic spots in Jiangsu to upgrade their portals and set up mobile phone WAP homepage so that tourists could log into websites using mobile phone whenever and wherever possible. Scenic spot staff could perform timely online communication with customers and issue scenic spot-specific recommendation advertisement and shopping information so as to improve service quality and consumer enthusiasm. Push forward the development of smart travel agency. The momentum of rapid development of ly.com, tuniu.com and other tourism related electronic commerce platforms in Jiangsu Province has laid a perfect foundation for the development of "smart travel agency". The development of "smart travel agency" enables tourists to experience "intelligence" and "wisdom" during the entire process of tourism information acquisition, tourism planning, payment for reservation of tourism products, tourism enjoyment, and tourism review \& evaluation.

\section{Environment Strategy: Optimize Comprehensive Tourism Environment}

Tour process is a process during which tourists pursue aesthetic pleasure. Tourists can't realize aesthetic appreciation unless they are in a perfect tourism environment. First, it's important to strengthen the environmental protection supervision \& management capacity building. Normalize and build environmental monitoring network in an accurate, timely, efficient and all-round manner. Encourage the public to participate in ecological environment protection and development. 
Establish and improve public participation system, where it's essential to fully listen to the opinions of the masses in case of plans, decisions and projects involving the masses' interests. Secondly, classify and organize the existing cultural resources of Jiangsu Province, and promote and embellish material culture, folk culture and spiritual culture from the perspective of market demand so as to bring economic benefits during culture inheritance. Thirdly, protect ancient building resources, protect and renovate key cultural relics. Furthermore, it's advisable to strengthen the instructions for the public in terms of tourism basics so that the residents could initiatively disclose the information on the tourism resources and culture etc. of Jiangsu Province to tourists from other provinces, thereby creating an excellent tourism-oriented regional culture atmosphere. Lastly, it's important to maintain a good market order. Establish a tourism service quality supervision system. Tourism industry associations and other organizations could perform regular follow-up supervision of guesthouses, hotels, travel agencies and tourism service personnel's service quality by dint of social resources and the supervisory role of news media, and establish occupational credit files and name removal announcement system for tourism practitioners. Make great efforts for price supervision at tourism market. Competent authorities of tourism are expected to check the implementation of price guidelines for scenic spots and catering industry through industry investigations in secret carried out irregularly.

\section{References}

[1] Wan Xucai, Ding Min, and Song Ping, A study on domestic tourists' satisfaction evaluation for Nanjing and the relevant regional differences, Economists.2004(1):246-247.

[2] Information on www.jssb.gov.cn/

[3] Fang Falin, Ji Wenjing et al, A study on marketing and action plan for domestic tourism market at Jiangsu Province, Beijing: Tourism Education Press, 2013.

[4] Dong Guanzhi, and Yang Fengying, A study on the system of evaluation on tourist satisfaction with tourist attraction, Tourism Tribune.2005(1):27-30.

[5] Yu Wanyuan, Feng Yafen, and Liang Jinmei, A tourist satisfaction based study on Hakka culture tourism development, Scientia Geographica Sinica.2013(7):824-829. 